УДК 141.113

DOI https: / / doi.org/10.32837 / yuv.v0i4.972

\title{
О. Остапенко,
}

кандидат юридичних наук,

доцент кафедри правового регулювання економіки

Харківського національного економічного університету

\section{ПРИНЦИПИ ПОЛІТИЧНОГО Й ІДЕОЛОГІЧНОГО ПЛЮРАЛІЗМУ: ПРОБЛЕМИ РЕАЛІЗАЦІЇ В УКРАЇНІ}

Становлення України як демократичної держави вимагає належного впровадження пов'язаних між собою принципів політичного й ідеологічного плюралізму, закріплених на рівні міжнародного стандарту у Загальній декларації прав людини 1948 р. (ст. 20), Конвенції про свободу асоціації та захист права на організацію 1948 р. (статті 2, 10), Конвенції про захист прав людини i основоположних свобод 1950 p. (ст. 11), Міжнародному пакті про громадянські і політичні права 1966 p. (ст. 22), та у національному законодавстві, зокрема у ст.ст. 15, 37 Конституції України, ст.ст. 4, 12 Закону України «Про політичні партії в Україні».

Окремі аспекти становлення засад політичного й ідеологічного плюралізму сучасності висвітлювалися у працях Г. Гончарової, С. Кононенка, Є. Лук'яненка, С. Лукаша, M. Остапенко, С. Троян, О. Уткіна й ін., а також зарубіжних авторів посттоталітарних, транзитивних, лабільних країн Центрально-Східної Європи, зокрема, Г. Зімона, Н. Розенблюма, В. Слободчикова, М. Мамардашвілі, K. Маннгейма, Р. Барта тощо. Проте пов'язаність принципів плюралізму з формуванням української національної ідеї, подальшою демократизацією суспільства та реалізації соціально-економічних реформ зумовлюють необхідність подальшого дослідження й наукову зацікавленість цією проблемою.

Метою статті $є$ дослідження проблем реалізації принципів політичного та ідеологічного плюралізму в Україні та визначення шляхів їх вирішення.

Висвітлення питань плюралізму відбувається в історичному, політологічному й юридичному напрямках. Науковці наголошують, що найважливішою вимогою плюралізму є запровадження в політиці й суспільстві різного роду стримувань і противаг, що збалансовують вПливи найбільш потужних політичних сил і дозволяють контролювати владу. Політичний плюралізм базується на наявності у переважної більшості громадян, партій та громадських організацій консенсусу, згоди щодо основних політичних цінностей загальної зацікавленості в збереженні й зміцненні держави, визнанні демократичних правил гри, що включають чесне суперництво в боротьбі за владу, терпимість до опозиціі, повага до закону, рішень більшості, прав людини, а також автономії й права меншості на власну думку та іï вільне відстоювання в рамках закону, відмова від антиконституційного використання сили для вирішення спірних питань [1].

Стаття 15 Конституції України закріплює, що суспільне життя в Україні грунтується на засадах політичної, економічної та ідеологічної багатоманітності. Так, плюралізм (від лат. - множинний) передбачає різноманітність поглядів, підходів, позицій, концепцій у правовій, політичній, економічній, культурній та іншій діяльності. Характерними ознаками розвинених форм плюралізму є багатоваріантність, вибір, альтернативність, свобода тощо [2]. Така багатоманітність виявляється 
в економічній сфері через існування форм власності, їх взаємодії Й здатності конкурувати між собою, у соціальній - через наявність різних соціальних груп, їх соціальних інтересів і розшаруванні (стратифікаціi) суспільства, у культурній - у розвитку різних напрямків i форм вияву самобутності людей, у формі гласності, свободі висловлювань, дискусій, різноманітності поглядів і думок, у духовній - через відсутність єдиного світогляду, повагу до духовного вибору людини та деідеологізацію суспільства.

Суспільна свідомість відображає суспільне буття з позицій певних соціальних груп, і як своєрідна інтегрована єдність ціннісного, нормативного та пізнавального структурних компонентів і представляє іi ідеологічний аспект. Оскільки ідеологія пов'язана як із суто раціонально-свідомісною, так i 3 ментально-психологічною сферами життя соціуму, іiі належить розглядати не просто як елемент суспільної свідомості, а й у ширшому соціокультурному контексті - як безпосередній продукт і суспільно-політичної, і водночас духовно-культурної діяльності суспільства [3]. Формування суспільної ідеології здійснюється через виховання, освіту, засоби масової інформації. Ідеологія $€$ ціннісною системою, що відображає ставлення людей до соціальної дійсності, існуючого суспільного порядку, дозволяє обгрунтовувати політичні цілі, ідеали, принципи, що покладаються в основу політичних програм партій, які визначають засоби ї реалізації. Закріплення ідеологічного плюралізму відбувається переважно через визнання й гарантування особистих і політичних прав і свобод.

Пов'язаність ідеологічного і політичного плюралізму полягає в тому, що перший породжує ідейні спори й ідеологічне розмаїття, що у свою чергу призводить до другого, який прагне відповідним чином їх реалізувати [3]. На думку $M$. Остапенко, важливими нормами політичного плюралізму $є$ : відмова від політичного насильства i диктатури; визнання народу абсолютним і суверенним джерелом влади; визнання верховенства закону і прав особистості; пошук політичного консенсусу і готовність до компромісів; вирішення найважливіших питань більшістю голосів і толерантне та терпиме ставлення до навіть нелояльної меншості тощо. Правове закріплення політичного плюралізму гарантує суспільству, з одного боку, захист від насильницької зміни суспільного ладу, 3 іншого - дотримання встановлених законів, «правил демократичної гри» з боку різних політичних партій і рухів [3].

Американський політолог Ф. Гросс виділяє у політичній ідеології (а) основні цінності («10 християнських заповідей», «Загальна декларація прав людини»); (б) допоміжні (інструментальні), корисні при певних обставинах, але не обов'язкові для всіх (надійність, пунктуальність, коректність, чесна гра, прибуток, уміння одягатися із смаком), - що допомагають людині підтримувати відносини з суспільством i робити політику, та (в) абсолютні цінності (свобода, рівність, справедливість) [4, с. 127]. Автор підкреслює, що при проведенні реформ необхідно чітко уявляти собі цінності даного суспільства, бо більшість 3 них, як правило, здійснюються за допомогою тиску. I тому важливо враховувати, зміна яких цінностей не призведе до опору з боку суспільства, а якими цінностями не можна нехтувати, бо це може породити соціально-політичну напругу.

Для розуміння процесів ідеологізації суспільства пропонуємо проаналізувати типи ідеологій. Традиційно ідеології поділяють на «ліві» (комуністичні й соціалістичні течіі) і «праві» (консервативні й національні). У сучасних умовах ліберальної демократії доцільно говорити про наявність демократичного центру, що функціонує в межах політичної системи, не заперечуючи законності поступових економічних і соціальних змін. На противагу центру, крайнє праве та ліве крила політичного 


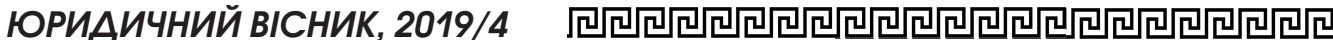

спектру - це переважно меншості, які прагнуть докорінно змінити конституційну та соціальну системи. Крайнє ліве крило політичного спектру представляє антикапіталістичну доктрину, праве пропонує зміни в націоналістичному напрямі [3].

Ф. Кирилюк виділяє шість типів ідеології: комунізм, соціал-демократія, лібералізм, консерватизм, націоналізм та фашизм [5, с. 413]; О. Соловйов - чотири: лібералізм/неолібералізм, консерватизм/неоконсерватизм, соціалізм, соціал-демократія і фашизм [6, с. 339-351]; К. Гаджієв - п'ять: лібералізм, консерватизм, соціал-демократія, марксизм і тоталітаризм [7, с. 121], але вважає, що реально конкурують нині лише три з них - лібералізм, консерватизм, соціал-демократія. В. Ісаков за ступенем розповсюдженості і впливу на суспільство ідеології поділяє на наступні види: ідеократичні - панування єдиної моноідеології, яку підтримує держава (Північна Корея, фашистська Німеччина, СРСР); клерикальні (Іран, арабські країни); перехідні, еклектичні (Східна Європа, пострадянські країни) та плюралістичні (Західна Європа, США) [8, с. 11]. При цьому політологи визначають, що зміни соціально-історичних і політико-правових умов життя тягнуть зміни ідеологічних програм i цінностей, зокрема, зміни традиційних ідеологічних орієнтацій чи-то в напрямку їхнього пом'якшення (це властиве комуністичній ідеологіï), чи-то в напрямку розширення (у цьому випадку можна послатися на зміни в соціал-демократичній ідеологіi). Так, розвиткові сучасної соціал-демократії властиве включення до ії базових положень таких ліберальних цінностей, як правова держава, демократичний плюралізм тощо [3].

У контексті типологізації ідеологій, які покладаються в основу політичних програм партій і визначають засоби їх реалізації, постає цікаве питання щодо дійсного плюралізму ідеологій и партій в Україні. За даними Міністерства юстиції України станом на 01.01.2019 р. в Україні зареєстровано 352 партії [9]. Проте 3 зареєстрованих партій ще у часи проголошення незалежності України більш-менш політично активною і такою, що не змінювала свої ідеологічні цінності $€$ лише Соціалістична партія України. за даними ЦВК щодо участі партій у виборах народних депутатів у 2019 р. із зареєстрованих у 1990-ті роки партій брала участь лише Партія зелених України, яка $€$ партією екологічної спрямованості та електорально активною була лише у 1990-х роках (були у складі парламенту після виборів 1998 р.).

Пропонуємо проаналізувати історію створення та діяльність партій, що були обрані до складу парламенту у 2019 р.: «Слуга народу», «Опозиційна платформа - За життя», ВО «Батьківщина», «Європейська солідарність» і «Голос» $[10,11]$.

Партія «Слуга народу» була створена у 2016 р. як сила, що пропонує зміни у країні: оновлення політичної системи, покращення якості політики та політиків, встановлення цінностей та принципів, яких вимагає сьогодні суспільство. Партія «Голос» була створена у травні 2019 р. на основі політичної партії «Платформа ініціатив», створеної у лютому 2015 р. $з$ метою повернути людину в центр держави, декларує демократичний підхід до ролітики, відокремлення грошей від політики.

Партія «Опозиційна платформа - За життя» була зареєстрована Міністерством юстиції України 9 грудня 1999 р. як Політична партія «За життя» (Всеукраїнське об'єднання Центр). У липні 2016 р. була перейменована в За життя, 14 грудня 2018 р. - в Опозиційну платформу - За життя. Співголовами партіі $€$ В. Рабинович (Всеукраїнське об'єднання Центр), Ю. Бойко (був головою Республіканської партії України, створеної у 2005 р., до серпня 2007 р., у 2006 р. балотувався в парламент по списку Опозиційного блоку НЕ ТАK!, створеного на базі СДПУ(о), у 2007 р. прийшов у парламент у складі Партії 
регіонів, восени 2014 р. - за списком партії Опозиційний блок) [12].

ВО «Батьківщина» зареєстровано у 1999 р. Його лідер - Ю. Тимошенко у 1997 - 1999 р. була першою заступницею голови ВО «Громада» П. Лазаренка, у лютому 2001 р. утворила Форум національного порятунку як громадську ініціативу, на грунті якої у листопаді 2001 р. був створений Блок Юлії Тимошенко. У листопаді 2011 року участь блоків політичних партій у парламентських виборах була заборонена. У результаті до «Батьківщини» під назвою «Об'єднана опозиція „Батьківщина“» увійшли партії «Реформи і порядок», Народний рух України, «Фронт змін», «За Україну!», «Народна самооборона», «Громадянська позиція», Соціально-християнської партії та Меджлісу кримськотатарського народу. I з 2002 р. партія представлена в усіх скликаннях парламенту [13].

«Європейська солідарність» (зареєстрована у 2000 р. як партія «Солідарність» на чолі з $M$. Антонюком, у 20142019 р. - «Блок Петра Порошенка «Солідарність», 32019 р. - «Європейська солідарність»). Видається цікавою історія трансформації партії: у 2001 р. партію «Солідарність» очолив П. Порошенко і у 2002 р. вона приєдналася до виборчого блоку В. Ющенка «Наша Україна», у 2013 р. «Солідарність» увійшла до ВО «Батьківщина», оскільки впродовж 10 останніх років не брала участі у парламентських або президентських виборах, як того вимагає Закон України «Про політичні партії в Україні», рішенням суду їі реєстраційне свідоцтво було анульовано. Внаслідок цього на основі неактивної партії Національний Альянс свободи та Украінського Патріотизму ( НАСТУП»), створеної у 2000 р. як «Всеукраїнська партія Миру і Єдності (ВПМЄ)», і перейменована у 2013 р. на Національний Альянс свободи та Українського Патріотизму («НАСТУП»), задля “упізнаваності” президентської сили на парламентських виборах у жовтні 2014 р. ii було перейменовано на «Всеукраїнське об’єднання «Солідарність». Треба зазначити, що практика використання партійної назви, яка тотожна або майже дослівно повторює назву іншої, чинної або вже неіснуючої партії не суперечить українському законодавству, хоча, до прикладу, у Грузії партіям заборонено законом використовувати ті назви, абревіатури і символи, які повторюють уже колись існуючі, навіть у ліквідованої партії, якщо з часу ii ліквідації пройшло менше 4 років. Цікавим фактом є те, що 6 жовтня 2014 р. Міністерство юстиції України зареєструвало ще один “клон” колишньої партії Петра Порошенка - Політичну партію "Солідарність” (реєстраційний номер - 252-п.п.), керівником якої значиться Костецький Станіслав Іванович, колишній голова Спілки поляків України [14]. У 2014 р. ВО «Солідарність» було перейменовано на «Блок Петра Порошенка, згодом - «Блок Петра Порошенка «Солідарність», яка після виборів у парламенті утворила фракцію, що об'єднала представників партії «Блок Петра Порошенка», колишніх членів партії «УДАР (Український Демократичний Альянс за Реформи) Віталія Кличка», низку журналістів, громадських активістів і політичних діячів. Серед 150 депутатів фракції на той час 43 були членами «Блок Петра Порошенка», 104 - безпартійними, троє - членами інших партій (Українська Народна Партія (M. I. Кучер), Конгрес Українських Націоналістів (А. Я. Лопушанський), Всеукраїнське об'єднання “Батьківщина” (С. І. Мельник) [14]. У 2019 р. партія була перейменована на «Європейську солідарність».

На підставі викладеного виникає питання: а чи можна вважати такі зміни у партії, їх перейменування, об’єднання чи роз'єднання реалізацією принципу політичного та ідеологічного плюралізму? На жаль, навряд чи. Такі трансформації переважно свідчать не про світоглядні цінності, прагнення до побудови демократичної, соціальної, 
правової держави, а лише про бажання до участі у політиці з метою

Ще одна ілюстрація порушення принципів політичного й ідеологічного плюралізму - невідповідність, на думку окремих суддів Конституційного Суду України, громадських експертів [15], Венеціанської комісії [16] окремих положень Закону України «Про засудження комуністичного та націонал-соціалістичного (нацистського) тоталітарних режимів в Україні та заборону пропаганди їньої символіки», який було визнано конституційним Рішенням Конституційного Суду України від 16 липня 2019 р. № 9-р/2019 у справі за конституційним поданням 46 народних депутатів України щодо відповідності Конституціï України (конституційності) Закону України «Про засудження комуністичного та націонал-соціалістичного (нацистського) тоталітарних режимів в Україні та заборону пропаганди іхньої символіки» [17]. Вказаний Закон був прийнятий 9 квітня 2015 р. 30 травня 2017 р. до Конституційного Суду України надійшло конституційне подання 46 народних депутатів України щодо відповідності Конституції України (конституційності) Закону України «Про засудження комуністичного та націонал-соціалістичного (нацистського) тоталітарних режимів в Україні та заборону пропаганди їхньої символіки» від 9 квітня 2015 року № 317-VII, провадження у справі було відкрито і з 22 листопада 2017 р. почався іï розгляд. Не можна не погодитися зі змістом грунтовного рішення Конституційного Суду України щодо легітимності мети Закону - недопущення повторення злочинів комуністичного та націонал-соціалістичного (нацистського) тоталітарних режимів, будь-якої дискримінації за національною, соціальною, класовою, етнічною, расовою або іншими ознаками у майбутньому, відновлення історичної та соціальної справедливості, усунення загрози незалежності, суверенітету, територіальній цілісності та національній безпеці України і його висновку про те, що пропаганда комуністичного режиму та нацистського режиму, публічне використання їхніх символів $€$ намаганням виправдати тоталітаризм та запереченням конституційних принципів і демократичних цінностей, захист яких є обов'язком усіх органів державної влади. Проте в окремій думці судді Конституційного Суду України Колісника В.П. стосовно Рішення Конституційного Суду України у справі за конституційним поданням 46 народних депутатів України щодо відповідності Конституції України (конституційності) Закону Украіни «Про засудження комуністичного та націонал-соціалістичного (нацистського) тоталітарних режимів в Україні та заборону пропаганди їхньої символіки» наведено аргументовану позицію щодо порушення принципу політичного плюралізму, деталізованого у ст. 37 Конституції України. Так, В.П. Колісник вказує, що «водночас положення Закону, яке передбачає можливість усунення зареєстрованої політичної партії 3 виборчого процесу в адміністративному порядку (частина п'ята статті 3 Політичні партіі, обласні, міські, районні організації або інші структурні утворення, передбачені статутом політичної партії, щодо яких центральним органом виконавчої влади, що реалізує державну політику з питань державної реєстраціï юридичних осіб, реєстрації (легалізаціi) об'єднань громадян, громадських спілок, інших громадських формувань, прийнято у визначеному Кабінетом Міністрів України порядку рішення про невідповідність їх діяльності, найменування та/або символіки вимогам цього Закону, не можуть бути суб'єктом виборчого процесу.), не може вважатися прийнятним у демократичному суспільстві та не відповідає частині четвертій статті 37 Конституції Украіни, згідно з якою «заборона діяльності об'єднань громадян може здійснюватися лише в судовому порядку». Для такого висновку $є$ всі підстави, адже 
участь у виборах $€$ визначальною та обов'язковою складовою діяльності політичної партії, без якої існування партії втрачає будь-який сенс, а партія перетворюється на політичну фікцію, адже «політичні партї в Україні сприяють формуванню i вираженню політичної волі громадян, беруть участь у виборах» (частина друга статті 36 Конституції України). Без участі у виборах відповідне об'єднання громадян втрачає ознаки політичної партії, що нівелює право громадян на об'єднання» [18].

Крім того, у висновку Веніціанської комісії було зазначено, що «на відміну від переліку символіки комуністичного тоталітарного режиму, цей перелік (символіки національно-соціалістичної партіі) є коротшим і чіткішим, обмежений виключно символами, пов'язаними з Німеччиною 1939-1945 років, ...закон мав би однаково регулювати обсяг та детальність опису діянь, пов'язаних з обома ідеологіями». Тому не можна не погодитися з думкою Д. Коркунова, що «як порушення можна кваліфікувати червону хустинку і в той же час не помічати символіки третього рейху в логотипах чисельних офіційних громадських формуваннях та політичних рухів» [19]. Юрист також зазначає, що «ще одним прикладом подвійних стандартів можна вважати прийнятий 09.04.2015 р. Закон «Про правовий статус та вшанування пам'яті борців за незалежність України у 20-му столітті», де визнаються та вшановуються на державному рівні Організація українських націоналістів, Українська повстанська армія та ін., ідеологічна складова діяльності яких викликає в суспільстві не менш суперечливе ставлення, ніж діяльність КПРС. В цьому випадку виникає правова колізія, коли одним Законом забороняється пропаганда, символіка та ідеологія національно-соціалістичного режиму, а іншим декламується підтримка та вшанування організацій, які створювалися та діяли у складі та під безпосереднім керівництвом нацистської Німеччини (на той час територія райхскомісаріату Украіни)» [19].

Підсумовуючи викладене, можемо зробити висновок, що сучасне украінське суспільство потребує забезпечення стабільності держави, гідного рівня матеріального і духовного життя людей, що здатна забезпечити лише демократична система цінностей, яка грунтується на політичному плюралізмі, на вільній ринковій економіці, рівності громадян перед законом. Функціонування даної системи цінностей у високорозвинених країнах Європи та світу підтримується відповідною інфраструктурою політичної соціалізації, як засобу відтворення зрілої демократичної політичної культури [20]. Складність політичної та економічної ситуації в країні, соціальне розшарування суспільства вимагають пошуку суспільного діалогу, компромісу і консенсусу між владою і народом. Захист національних інтересів в умовах формування української державності, пошук національної ідеї для формування громадянського суспільства вимагає вирішення гострих політичних проблем щодо визначення сутності i змісту патріотизму (з метою уникнення руйнівного псевдопатріотизму), визначення статусу мов у поліетнічній Україні, формування інформаційного простору, вільного від пропаганди, маніпуляцій свідомістю, незалежності й об'єктивності мас-медіа і найголовніше - підвищення рівня політичної і правової культури громадян, а також рівня захисту прав людини.

Демократизація України, забезпечення політичної стабільності $з$ метою недопущення дестабілізації суспільства зумовлена належною реалізацією таких засад конституйійого ладу як політичний ma ідеологічний плюралізм $і$ вимагає належного впровадження пов'язаних між собою принциипів політичного й ідеологічного плюралізму, закріплених на рівні міжнародного стандарту у Загальній декларації 
прав людини 1948 р., Конвенції про свободу асоціаціi та захист права на організацію 1948 р., Конвениії про захист прав людини $i$ основоположних свобод 1950 р., Міжнародному пакті про громадянські і політичні права 1966 р., та у національному законодавстві, зокрема у ст.cm. 15, 37 Конституиії України, ст.ст. 4, 12 Закону України «Про політичні партії в Україні». Сучасне українське суспільство потребує забезпечення стабільності держави, гідного рівня матеріального $і$ духовного життя людей, що здатна забезпечити лище демократична система изіностей, яка трунтується на політичному плюралізмі, на вільній ринковій економіці, рівності громадян перед законом. Функиіонування даної системи цінностей у високорозвинених країнах Європи та світу підтримується відповідною інфраструктурою політичної сочіалізації, як засобу відтворення зрілої демократичної політичної культури. Складність політичної та економічної ситуації в країні, соцуіальне розшарування суспільства вимагають пошуку суспільного діалогу, компромісу $i$ консенсусу між владою $i$ народом. Захист національних інтересів в умовах формування української державності, пошук національної ідеї для формування громадянського суспільства вимагає вирішення гострих політичних проблем щодо визначення сутносmi i змісту патріотизму (з метою уникнення руйнівного псевдопатріотизму), визначення статусу мов y поліетнічній Україні, формування інформаційного простору, вільного від пропаганди, маніпулящиій свідомістю, незалежності й об'єктивності мас-медіа $i$ найголовніше - підвищення рівня політичної $і$ правової культури громадян, а такон рівня захисту прав людини.

Ключові слова: плюралізм, ідеологія, світогляд, політична партія, держава, демократія, розвиток.

\section{Ostapenko O. PRINCIPLES OF POLITICAL AND IDEOLOGICAL PLURALISM: PROBLEMS OF IMPLEMENTATION IN UKRAINE}

Democratization of Ukraine, ensuring political stability in order to prevent destabilization of society is dependent on the proper application of such constitutional principles as political and ideological pluralism and requires the proper implementation of related principles of political and ideological pluralism, enshrined at the level of the international standard in the the Universal Declaration of Human Right of 1948, The Convention on Freedom of Association and the Protection of the Right to Organize of 1948, the Convention for the Protection of Human Rights and Fundamental Freedoms of 1950, the International Covenant on Civil and Political Rights of 1966, and in national legislation, in particular Art. 15, 37 of the Constitution of Ukraine, Art. 4, 12 of the Law of Ukraine "On Political Parties in Ukraine". In modern Ukrainian society the stability of the state, a decent level of material and spiritual life of people, which is capable of providing only a democratic value system based on political pluralism, a free market economy, equality of citizens before the law must be ensured. The functioning of this value system in the highly developed countries of Europe and the world is supported by an appropriate infrastructure of political socialization, as a means of restoring a mature democratic political culture. The complexity of the political and economic situation in the country, social stratification require the search for public dialogue, compromise and consensus between the authorities and the people. Protecting national interests in the conditions of formation of the Ukrainian statehood, search for a national idea for the formation of civil society requires the solution of acute political problems in determining 
the essence and content of patriotism (in order to avoid destructive pseudopatriotism), determining the status of languages in poly-ethnic Ukraine, forming an informative space, free of propaganda, manipulation of consciousness, independence and objectivity of the mass media and most importantly - raising the level of political and legal culture of citizens, as well as the level of human rights protection.

Key words: pluralism, political party, state, democracy, development.

\section{Література}

1. Щербина Н.Ф., Махінла Ю.Б. Політико-ідеологічний плюралізм в сучасній україні: теоретичні й практичні аспекти. «Молодий вчений», № 4 (31), квітень, 2016 р. С. 327-332.

2. Юридична енциклопедія: В $6 \mathrm{~m}$. / Редкол.: Ю. С. Шемшученко (голова редкол.) та ін. К.: «Укр. енцикл.», 1998 /Електронний ресурс/. - Режим доступy: http:/ / leksika.com.ua/14191125/legal/plyuralizm

3. Остапенко М. Ідеологічний плюралізм: проблема необхідності розвитку $i$ збереження иілісності демократичного суспільства

4. Гросс Ф. Идеологии, иели и ценности / Ф. Гросс / / Общественные науки за рубежом. Сер. 1. 1989. № 6. С. 121-145.

5. Політологія: Навчально-методичний комплекс / За ред. проф. Ф. М. Кирилюка. К.: Центр навчальної літератури, 2004. $704 \mathrm{c}$.

6. Соловьев А. И. Политология: Политическая теория, политические технологии: Учебник для студентов вузов / А. И. Соловьев. М.: Аспект Пресс, 2003. $559 \mathrm{c}$.

7. Гаджиев К. С. Введение в политическую науку. - 2-е изд./ К. С. Гаджиев. М.: Логос, 1999. 352 c

8. Исаков В.Б. Право и идеология в демократическом обществе / / Гражданское общество в России и за рубежом. 2011. № 1. C. 11-15.

9. Відомості щодо зареєстрованих у встановленому законом порядку політичних партій станом на 01.01.2019 року Відомості щодо зареєстрованих у встановленому законом порядку політичних партій станом на 01.01.2019 року https: / / minjust.gov.ua $/ \mathrm{m} / 4561$
10. Відомості щзоо реєстрації виборчих списків кандидатів у депутати (вибори 2019 р.) [Електронний ресурс]. - Режим docmyny: https: / / wrw.cvk.gov.ua/pls / und2019/ wp400pt001f01=919.html

11. ЦВКназвалапартї̈, щовзяли 225 місиь y Верховній Раді [Електронний ресурс]. Pежим docmyny: https: / / www.pravda.com. ua / news / 2019/08/3/7222696/

12. Оппозиционная платформа - $3 a$ життя [Електронний ресурс/. - Режим docmyny: https://file.liga.net/parties / za-zhittya

13. Всеукраїнське об’єднання «Батьківщина» [Електронний ресурс]. - Режим docmyny: https://wrw.chesno.org/ party/222/

14. Історія партії «Блок Петра Порошенка» [Електроннии pecypcl. - Режuм docmyny: https: / / rada. oporaua.org / analityka/istorii-partii/5119. istoriia-fraktsii-blok-petra-poroshenka

15. Висновок Центру політико-правових реформ щодо відповідності Конституції України Закону України «Про засудження комуністичного та націонал-соціалістичного (нацистського) тоталітарних режимів в Україні та заборону пропаганди їхньої символіки» від 9 квітня 2015 року № 317-VII Висновок Центру політико-правових реформ щодо відповідності Конституиії України Закону України «Про засудження комуністичного та націонал-соціалістичного (нацистського) тоталітарних режимів в Україні та заборону пропаганди їхноӧ символіки» від 9 квітня 2015 року № 317-VII /Електронний ресурс). - Режим доступy: http:// pravo.org.ua/ua/news / 20872463-visnovoktsentru-politiko-pravovih-reform-schodovidpovidnosti-konstitutsiyi-ukrayini-zakonuukrayini-pro-zasudgeennya-komunistichnogota-natsional-sotsialistichnogo-natsistskogototalitarnih-regeimiv-v-ukrayini-ta-zaboronupropagandi-yihnoyi-simvoliki-vi

16. Спільний проміжний висновок щодо Закону України "Про засудження комуністичного та націонал-соціалістичного (нацистського) тоталітарних режимів в Україні та заборону пропаганди їхньої символіки», ухвалений Венеціанською комісією на 105-му пленарному засіданні Венеція (18-19 грудня 2015 року) /Електронний pecypcl. - Pежим docmyny: https: / / wшw. legislationline.org / download / id / 6157 / file / CDL-AD2015041-ukr.pdf

17. Рішення Конституцзійного Суду України у справі за конституційним подан- 


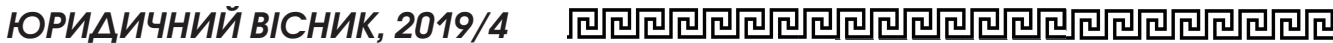

ням 46 народних депутатів Украӥни щзодо відповідності Конституиї України (конституизйності) Закону Украӥни «Про засу дження комуністичного та націонал-соціалістичного (нацистського) тоталітарних режимів в Україні та заборону пропаганди іхньої символіки» [Електронний ресурс]. Pежим доcmyny: https: / / zakon.rada.gov. ua / laws / show / en / v009p710-19

18. Окрема думка судді Конституиійного Суду України Колісника В.П. стосовно Рішення Конституијйного Суду України у справі за конституиійним поданням 46 народних депутатів України щодо відповідності Конституиії Укра- їни (конституційності) Закону України «Про засудження комуністичного та націонал-соціалістичного (нацистського) тоталітарних режимів в Україні та заборону пропаганди їхньӧ символіки» [Електронний ресурс]. - Режим доступу: https: / / zakon.rada.gov.ua/laws / show/ en / nd09d710-19\#n2

19. Коркунов Д. Подвійні стандарти впровадження Закону «про декомунізаиію» [Електронний ресурс]. - Режим docmyny: https://uspishna-varta.com/ novyny / podv\%D1\%96jn\%D1\%96standarti-vprovadzhennya-zakonu-prodekomun\%D1\%96zac\%D1\%96yu

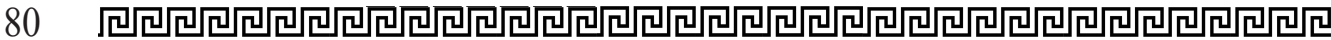

